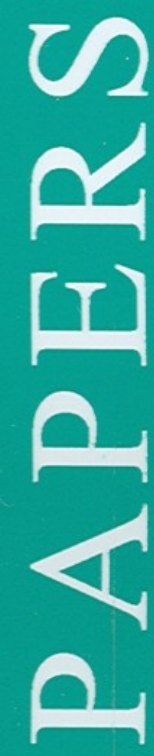

Efficiency of Large Scale Manufacturing in Pakistan: A Production Frontier Approach

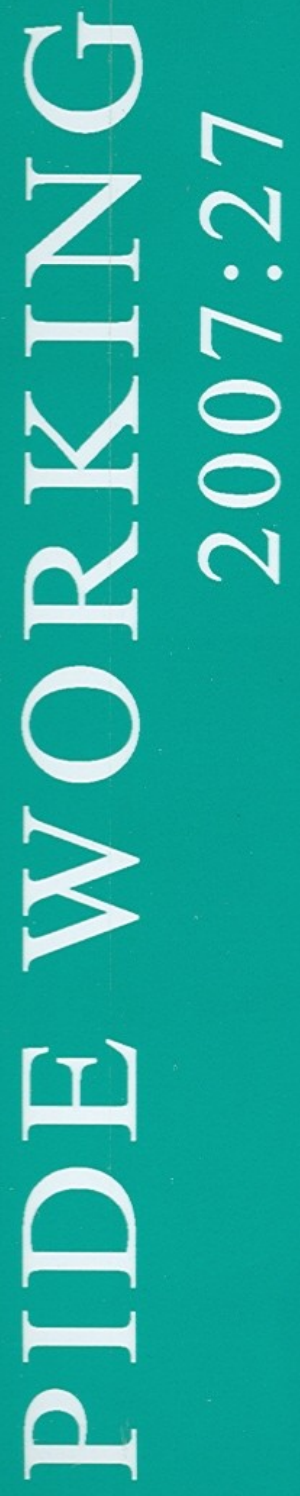

Tariq Mahmood

Ejaz Ghani

Musleh-ud Din 


\section{Efficiency of Large Scale Manufacturing in Pakistan: A Production Frontier Approach}

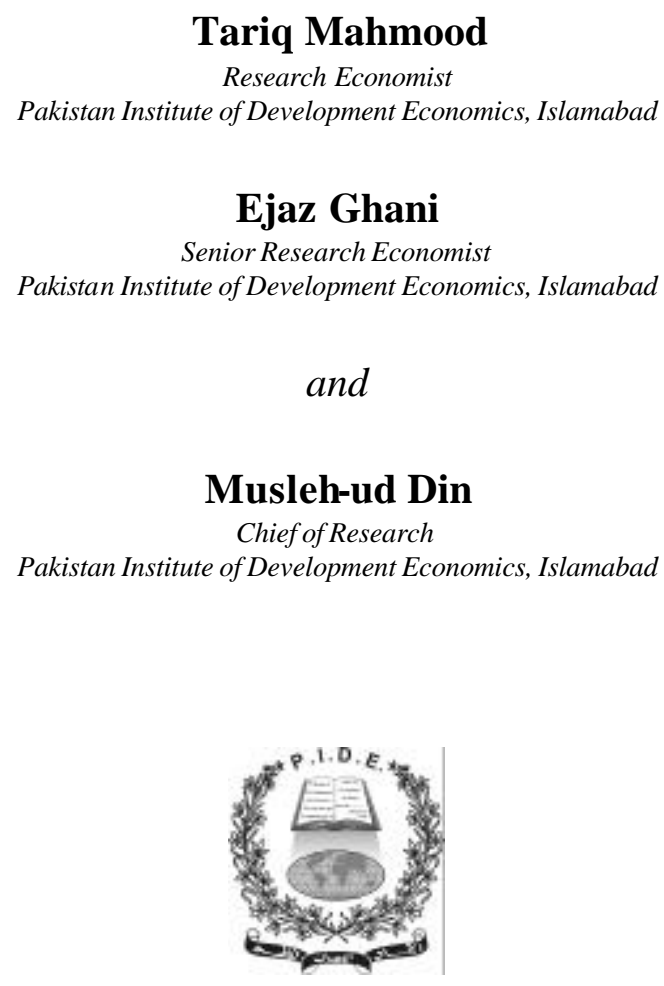

PAKISTAN INSTITUTE OF DEVELOPMENT ECONOMICS ISLAMABAD 
All rights reserved. No part of this publication may be reproduced, stored in a retrieval system or transmitted in any form or by any means-electronic, mechanical, photocopying, recording or otherwise-without prior permission of the author(s) and or the Pakistan Institute of Development Economics, P. O. Box 1091, Islamabad 44000.

\section{(C) Pakistan Institute of Development}

\section{Economics, 2007.}

Pakistan Institute of Development Economics

Islamabad, Pakistan

E-mail: publications@ @ide.org.pk

Website: http://www.pide.org.pk

Fax: $\quad+92-51-9210886$

Designed, composed, and finished at the Publications Division, PIDE. 


\section{O N T E N T S}

$\begin{array}{lc} & \text { Page } \\ \text { Abstract } & \mathrm{v} \\ \text { 1. Introduction } & 1 \\ \text { 2. Review of Literature } & 1 \\ \text { 3. Methodology and Data } & 5 \\ \text { 4. Empirical Results } & 7 \\ \text { 5. Concluding Remarks } & 10 \\ \text { Appendix } & 11 \\ \text { References } & 14\end{array}$

\section{List of Tables}

Table 1. Regression Results for the Year 1995-96 8

Table 2. Regression Results for the Year 2000-01 8

Table 3. Industry-wise Mean Efficiency Scores 9 


\begin{abstract}
This paper examines the efficiency of the large scale manufacturing sector of Pakistan using the stochastic production frontier approach. A stochastic production frontier is estimated for two periods-1995-96 and 2000-01-for 101 industries at the 5-digit PSIC. The results show that there has been some improvement in the efficiency of the large scale manufacturing sector, though the magnitude of improvement remains small. The results are mixed at the disaggregated level: whereas a majority of industrial groups have gained in terms of technical efficiency, some industries have shown deterioration in their efficiency levels.
\end{abstract}

JEL classification: D24, L6, O14, P27

Keywords: Manufacturing Industries, Technical Efficiency, Stochastic

Frontier Analysis, Data Envelopment Analysis 


\section{INTRODUCTION}

The large scale manufacturing sector in Pakistan has gained increasing prominence over the years with its share in output rising to about 13 percent in 2005-06 from 5.67 percent in 1959-60. ${ }^{1}$ The sector has operated amid varying policy environments ranging from outright import substitution in the early years to a more deregulated and liberal environment in the recent years driven largely by concerns to improve the efficiency of the industrial sector which is critical for attaining greater competitiveness. While industrial and trade policy reforms in recent years have exposed domestic enterprises to greater internal and external competition, most of these enterprises continue to seek state patronage and have yet to re-position themselves to compete effectively in the global market place. Furthermore, the trade policy still has an import substitution bias for certain critical sectors whose imports are subject to tariff peaks and this raises concerns on their efficiency.

This study aims to assess the efficiency of large scale manufacturing sector in Pakistan using the production frontier approach. Section 2 reviews the literature while Section 3 sets out the methodology and discusses data employed in the study. Section 4 analyses empirical findings, and Section 5 concludes the discussion.

\section{REVIEW OF LITERATURE}

Since the seminal work of Aigner, Lovell, and Schmidt (1977), who first proposed the stochastic production frontier technique, a growing body of literature has used the approach to estimate industrial efficiency. Taymaz and Saatci (1997) analyse the extent and importance of technical progress and efficiency in Turkish manufacturing industries. The rate and direction of technical change in three industries - textiles, cement, and motor vehicles - are estimated by using panel data on plants for the period 1987-92, using CobbDouglas, and translog stochastic frontier production functions. In addition to traditional inputs like labour, raw materials, energy and capital inputs etc., other factors like sub-contracting, advertising intensity, ownership type are also included in the analysis. The results show that there are significant inter-sectoral differences in the rates of technical change and the factors influencing technical efficiency at the plant level. Subcontracting is found to improve the efficiency of user firms in the textile, cement, and motor vehicles industries. The ownership type and the source of technology are found to be important determinants of

\footnotetext{
${ }^{1}$ Pakistan Economic Survey (Various Issues).
} 
plant-level efficiency. Other important factors in efficiency are legal status of the firm, product characteristics, and regional agglomeration. The study finds a positive relationship between the plant size and technical efficiency in the cement and motor vehicles industries.

Ikhsan-Modjo (2006) examines the patterns of total factor productivity growth and technical efficiency changes in Indonesia's manufacturing industries over the period 1988-2000. The study uses the data incorporating both the liberalisation years and the crisis/post crisis years sourced from an annual panel survey of manufacturing establishments. Following the approach of Battese and Coelli (1992), a translog frontier production function is estimated. Gross output is regressed on inputs like the cost of capital, wages, intermediate inputs and energy, and the study finds that technical progress is the most important factor in explaining TFP growth in the Indonesian manufacturing sector.

Tripathy (2006) examines efficiency gap between foreign and domestic firms in eleven manufacturing industries of India during 1990-2000. Two different techniques, i.e. stochastic frontier and data envelopment analysis are used to measure efficiency of the firms. The study assumes a Cobb-Douglas technology and estimates stochastic production and cost frontier in each industry to measure technical efficiency and cost efficiency of each firm as well as to obtain some inference on allocative efficiency. The stochastic frontier estimations show that generally foreign firms are technically efficient with significant mean difference as compared with the domestic firms. The data envelop technique comes at the same conclusions albeit with a few exceptions. The average cost efficiency scores in terms of stochastic frontier show mixed results: it indicates that there is a weak evidence for foreign firms to be allocatively inefficient in drugs and pharmaceuticals as compared with the domestic firms since the former are on average technically efficient but cost inefficient. On the other hand the data envelop results show that foreign firms are generally more efficient than domestic firms in terms of allocative efficiency. The evidence indicates that foreign firms tend to use more labour than capital as compared with domestically owned firms and hence the study concludes that the foreign firms are not using an inappropriate technology.

Alvarez and Crespi (2003) explore differences in technical efficiency in Chilean manufacturing firms. The authors use plant survey data and apply nonparametric frontier Data Envelopment Analysis. A stratified random sample is employed and firms are classified according to ISIC (3-digits) classification. It is found that the average fficiency of the sample is 65 percent with a large heterogeneity among sectors, and that the professional and scientific equipment sector exhibits 91 percent efficiency, while agro-industries and textiles have much lower efficiency levels at 49 percent and 34 percent respectively. Efficiency estimates are further used in regression analysis to exp lore the factors influencing efficiency levels, and the study finds no relationship between firm size and level of efficiency. The key attributes of the efficient firms are found to 
be access to credit, labour skills, experience and education level of firm owner, and orientation to international markets etc.

Njikam (2003) assesses the effects of trade reform on firm-specific technical efficiencies in Cameroon manufacturing using firm-level balanced panel data for the period from 1988-89 to 1997-98. This period is further subdivided into two sub-periods: the pre trade reform period covering the years 1988-89 to 1991-92, and the post trade reform period covering the years 199495-1997-98. A Cobb-Douglas stochastic production frontier is estimated for each industrial sector. Results indicate that relative to the pre-reform scores, the post-reform average technical efficiency increased in six of eight industries and in total manufacturing. The pre-reform firm-specific technical efficiencies decreased on average at the annual rate of 0.76 percent, while the post-reform firm-specific technical efficiencies increased on average at an annual rate of 1.4 percent. The study concludes that the trade reform provided an enabling environment for improving firm-level technical efficiency.

In the context of Pakistan's economy, Burki and Khan (2005) analyse the implications of allocative efficiency on resource allocation and energy substitutability. The study covers the period 1969-70 to 1990-91 and utilises pooled time series data from Pakistan's large scale manufacturing sector to estimate a generalised translog cost function. The study also computes factor demand elasticities and elasticities of substitution by using the parameters of the estimated generalised cost function. The results indicate strong evidence of allocative inefficiency leading to over- or under-utilisation of resources and higher cost of production. Input-mix inefficiency takes the form of overutilisation of raw material and capital vis-à-vis labour and energy. The study finds that allocative inefficiency of firms has on average decreased the demand for labour by 0.19 percent and increased the demand for energy by 0.12 percent. Own price elasticities of factors of production imply that the demand for capital is much more sensitive to its own price than the demand for labour. However, the elasticity of substitution between all factors is found out to be positive, which implies that they are substitutes. This is attributed to installation of new but more energy-efficient capital. The new machinery and plants, although more energy-intensive and raw material saving, leave the share of capital and labour unchanged.

Some studies have utilised the Data Envelopment Analysis (DEA) to explore the question of industrial efficiency. Using a sample of 44 Indian pharmaceutical companies for the period 1992 to 2000, Saranga and Phani (2004) attempt to investigate whether internal efficiencies have any role to play in the growth of companies in a constantly changing dynamic environmental context. Companies are grouped according to three different criteria including the type of ownership, type business, and firm size. The purpose is to see how the companies in different categories fare in terms of efficiency ratings. Inputs selected are cost of production and selling, cost of material, and cost of manpower whereas outputs are profit 
margin, net sales, and exports. The results show that size of a company does not dictate the internal efficiency ratings; however indigenous firms, which are in the business of both bulk and formulations, have an edge over MNCs and over firms with only formulations business.

Jajri and Rahmah (2006) analyse trend of technical efficiency, technological change and TFP growth in the Malaysian manufacturing sector. The data come from the Industrial Manufacturing Survey of 1984 to 2000 collected by the Department of Statistics, Malaysia. The authors use Data Envelopment Analysis (DEA) to calculate output-oriented Malmquist indices of Total Factor Productivity growth, technological change, and technical efficiency change. Technical efficiency change (catch-up) measures the change in efficiency between current $(t)$ and next $(t+1)$ periods, while the technological change (innovation) captures the shift in frontie $r$ technology. Seven industries are chosen viz. food, beverages and tobacco; textile, wearing apparel and leather; wood and wood products; paper and paper products; chemicals, petroleum, coal, rubber and plastic products; non-metallic mineral and iron and steel products industries. Input variables are capital and labour whereas value added is used as output. It is found that Total Factor Productivity Growth is mainly driven by technical efficiency. The industries that experienced high technical efficiency are food, wood, chemical and iron products. Analysis by industry shows that there is no positive relationship between capital intensity and efficiency, technological change and Total Factor Productivity growth.

Lee and Kim (2006) analyse the effects of research and development (R\&D) on Total Factor Productivity growth in manufacturing industries, using a sample of 14 OECD (Organisation for Economic Cooperation and Development) countries ${ }^{2}$ for the years 1982-1993. With the assumption of constant returns to scale technology, the Malmquist Productivity Index and ts components are computed using two traditional inputs i.e. labour and capital; then the exercise is repeated with the stock of R \& D capital as an additional input. Inclusion of R \& D capital is found to be statistically significant and the introduction of R \& D capital as an additional input reduces the TFP measures on average by 10 percent. This is attributed to “costly" R \& D capital formation as opposed to "costless" productivity growth when only labour and fixed capital are considered. It is also found that it is technological progress rather than efficiency catch up that is driven by the accumulation of R \& D capital. Spillovers of R \& D capital are tested using regression analysis. Two types of spillovers are considered viz. domestic R \& D spillovers across industries and international spillovers within a single industry. Domestic R \& D capital stocks and foreign R \& D capital stocks for different industries are used for this purpose. It is found that productivity gains in manufacturing industries depend significantly on $\mathrm{R}$ \& D spillovers, especially for an economy that is more open to international trade.

${ }^{2}$ The sample consists of Canada, Denmark, Finland, France, Germany, Italy, Japan, Korea, Netherlands, Norway, Spain, United Kingdom, and United States. 


\section{METHODOLOGY AND DATA}

This study utilises the Stochastic Frontier (SF) technique, originally proposed by Aigner, Lovell, and Schmidt (1977), to estimate a production frontier which will serve as bench mark to estimate the technical efficiencies of various industries. The study covers 101 industries for the years 1995-96 and 2000-01. So, it is a comparative study of two cross-sections.

The Stochastic Production Frontier is assumed to be of Cobb-Douglas form with a composite error term:

$$
\ln Y=\beta_{0}+\beta_{1} \ln K_{i}+\beta_{2} \ln L_{i}+\beta_{3} \ln I C_{i}+\beta_{4} \ln N I C_{i}+v_{i}-u_{i} \quad i=1 \cdots \cdots N
$$

Where: $Y_{i}$ is output of the $i$ th industry,

$K_{i}$ is the amount of capital used in the $i$ th industry,

$L_{i}$ is the average number of persons engaged in the $i$ th industry,

$I C_{i}$ is the industrial cost in the $i$ th industry,

$N I C_{i}$ is the non-industrial cost in $i$ th industry,

$v_{i}$ is a component of the error term with normal distribution i.e.

$$
v_{i} \sim N\left(0, \sigma_{v}^{2}\right)
$$

$u_{i}$ is a component of error term with half-normal distribution ${ }^{3}$ i.e.

$$
u_{i} \sim N^{+}\left(0, \sigma_{u}^{2}\right)
$$

$N$ is the total number of industries.

The symmetric error term $v_{i}$ is the usual noise component to allow for random factors like measurement errors, weather, strikes etc. The non-negative error term $u_{i}$ is the technical inefficiency component. The Ordinary Least Square estimation of the above model provides consistent estimates of $\beta_{i}$, but not of $\beta_{0}$. More importantly, we cannot obtain efficiency estimates through OLS [Kumbhakar and Lovell (2000)]. This issue is resolved by applying Maximum Likelihood estimation technique to obtain consistent parameter estimates as well as efficiency scores.

Aigner, Lovell, and Schmidt (1977) derived the likelihood function of the model based upon two parameters, $\mathrm{s}_{s}{ }^{2}=\mathrm{s}_{u}{ }^{2}+\mathrm{s}_{v}{ }^{2}$ and ? $=\mathrm{s}_{u} / \mathrm{s}_{v}(0=?=8)$. Battese and Corra (1977) replaced ? with ? $=\mathrm{s}_{u}{ }^{2} / \mathrm{s}_{\mathrm{s}}{ }^{2}(0=?=1)$. The latter parameterisation will be used in this paper. The likelihood function under this parameterisation is given by:

$$
\log (L)=-(N / 2) \log (\mathrm{p} / 2)-(\mathrm{N} / 2) \log \left(\mathrm{s}_{\mathrm{s}}^{2}\right)+\sum_{i=1}^{N} \log \left[1-\Phi\left(z_{i}\right)\right]
$$

\footnotetext{
${ }^{3}$ Some writers have used different assumptions about distribution of $u_{i}$. Afriat (1972) assumes $u_{i}$ to have a gamma distribution; Stevenson (1980) uses truncated normal distribution; and Greene (1990) uses two-parameter gamma distribution.

${ }^{4}$ The computer programme FRONTIER version 4.1, written by Tim Coelli, is used to obtain parameter estimates as well as the efficiency scores.
} 


$$
-\left(1 / 2 \mathrm{~s}_{\mathrm{s}}^{2}\right) \sum_{i=1}^{N}\left(1 y_{i}-1 x_{i}^{\prime} \beta\right)^{2}
$$

where

$\left.z_{i}=\left[\begin{array}{llll}(1 & y_{i} & -1 & x^{\prime} \beta\end{array}\right) / \sigma_{s}\right] \sqrt{\gamma /(1-\gamma}$ and $\Phi($.$) is the distribution function of a$ Standard normal variable.

The estimated model forms the basis for computing a predictor of technical efficiencies. Battese and Coelli (1988) suggest the following predictor of technical efficiencies:

$$
T E_{i}=E\left[\exp \left(-u_{i}\right) \mid \mathrm{e}_{\mathrm{i}}\right]
$$

Where $e_{i}=v_{i}-u_{i}$ and $E$ is the expectation operator. The above expression measures how far a firm lies below the frontier after allowing for random errors.

The next step is to check the significance of inefficiencies estimated by the model, i.e. to test the null hypothesis of no inefficiencies against the alternative hypothesis that inefficiencies are present. As suggested by Coelli (1995), a one-sided likelihood ratio test with a mixed chi-square distribution $\left(1 / 2 \chi_{0}^{2}+1 / 2 \chi_{1}^{2}\right)$ is appropriate here. Therefore, the null hypotheses is rejected if $L R>\chi_{1}^{2}(2 \alpha)$.

The data for the year 1995-96 are obtained from the Census of Manufacturing Industries (1995-96), ${ }^{5}$ whereas data for 2000-01 are obtained from the summary tables prepared by the Federal Bureau of Statistics. ${ }^{6}$ In all, 101 large-scale manufacturing industries are selected. The excluded industries are those which either do not have common industry codes or fall in some "other" category. Two industries, viz. Matches and Plastic Footwear, are excluded due to their negative value added in the year 1995-96.

The following is a brief description of the variables:

\section{Output}

CMI reports value added as well as contribution to GDP. Value added reported in CMI does not allow for non-industrial costs. So we have used contribution to GDP as output which equals value of production minus industrial cost minus net non-industrial cost.

\section{Capital}

Capital consists of land and building, plant and machinery and other fixed assets which are expected to have a productive life of more than one year and are in use by the establishment for the manufacturing activity.

\footnotetext{
${ }^{5}$ This is the latest available published CMI.

${ }^{6} \mathrm{http}: / /$ www.statpak.gov.pk/depts/fbs/statistics/manufacturing_industries/cmi_2001.html.
} 


\section{Labour}

Labour includes employees, working proprietors, unpaid family workers and home workers.

\section{Industrial Cost}

Industrial cost consists of cost of raw materials, fuels and electricity consumed, payments for work done, payments for repairs and maintenance and cost of goods purchased for resale.

\section{Non-industrial Cost}

Non-industrial Cost consists of cost of payments for transport, insurance payments, copy rights and royalties, postage, telegraph and telephone charges, printing and stationery costs, legal and professional expenses, advertising and selling expenses, traveling expenses and other such expenses incurred by the establishment.

\section{EMPIRICAL RESULTS}

The model is estimated by maximum likelihood method for both the periods and the results are reported in Tables 1 and 2 . All variables are statistically significant for both years except that of labour, which is insignificant for the year 2000-01. A possible explanation may be that the presence of rigidities in terms of worker lay off $^{7}$ may prevent firms from an optimal utilisation of the labour input which may become redundant owing to the adoption of more efficient technologies. That such technological developments have indeed taken place is corroborated by Burki and Khan (2004) who note that "traditional labour intensive technologies have gradually been replaced with more state of the art efficient technologies". The magnitude of the parameter gamma is 0.72 in 1995-96 and 0.64 in 2000-01; an indication that inefficiencies are the major component of the composite error terms in both the periods.

The likelihood ratio test of one-sided error gives a value of 4.3 for the year 1995-96 (significant at 95 percent) and 1.3 for the year 2000-01 (significant at 88.5 percent); implying that the use of stochastic frontier is justified.

Overall, the mean efficiency score increased from 0.58 in $1995-96$ to 0.65 in 2000-01, indicating an improvement in efficiency of the large scale manufacturing sector ${ }^{8}$ (see appendix for detailed efficiency scores). The results are, however, mixed at the disaggregated level. Table 3 reports the mean efficiency scores of various industries at the 3-digit level. In 1995-96, the top five industries in terms of their efficiency levels included tobacco

\footnotetext{
${ }^{7}$ Due, perhaps, to trade unions and strict labour laws etc.

${ }^{8}$ It is important to note that the efficiency scores in each period measure technical efficiency in relation to the respective frontier in each period.
} 
Table 1

Regression Results for the Year 1995-96

\begin{tabular}{lcc}
\hline Variables & Coefficients & $t$-values \\
\hline Constant & 0.82 & $1.56^{*}$ \\
Capital & 0.18 & $2.30^{* *}$ \\
Labour & 0.3 & $2.73^{* *}$ \\
Industrial Costs & 0.36 & $3.42^{* *}$ \\
Non-Industrial Costs & 0.28 & $2.52^{* *}$ \\
sigma-squared $\left(\mathrm{s}_{s}{ }^{2}=\mathrm{s}_{u}{ }^{2}+\mathrm{s}_{v}{ }^{2}\right)$ & 0.96 & $4.20^{* *}$ \\
Gamma $\quad\left(?=\mathrm{s}_{u}{ }^{2} / \mathrm{s}_{s}{ }^{*}\right)$ & 0.72 & $5.26^{* *}$ \\
LR test of the one-sided error $=4.2997$ & & \\
with number of restrictions $=1$ & & \\
\hline *Significant at 0.10 level of significance. & & \\
** Significant at $0 . .01$ level of significance. & &
\end{tabular}

Table 2

Regression Results for the Year 2000-01

\begin{tabular}{lcc}
\hline Variables & Coefficients & $t$-values \\
\hline Constant & 0.26 & 0.53 \\
Capital & 0.36 & $5.19^{* *}$ \\
Labour & 0.08 & 0.72 \\
Industrial Costs & 0.5 & $5.73^{* *}$ \\
Non-Industrial Costs & 0.1 & $1.54^{*}$ \\
sigma-squared $\left(\mathrm{s} \mathrm{s}_{\mathrm{s}}{ }^{2} \mathrm{~s}_{\mathrm{u}}{ }^{2}+\mathrm{s}_{\mathrm{v}}{ }^{2}\right)$ & 0.62 & $3.34^{* *}$ \\
Gamma $\left(?=\mathrm{s}_{\mathrm{u}} / \mathrm{s}_{\mathrm{s}}{ }^{*}\right)$ & 0.64 & $2.92^{* *}$ \\
LR test of the one-sided error $=1.3446$ & & \\
with number of restrictions $=1$ & & \\
\hline *Significant at 0.10 level of significance. & &
\end{tabular}

**Significant at 0.01 level of significance.

manufacturing, petroleum refining, other non-metallic mineral products, other manufacturing, electrical machinery and supplies. Among this group, while the level of efficiency of petroleum refining and electrical machinery and supplies improved marginally in 2000-01, the efficiency levels of tobacco manufacturing, other non-metallic mineral products, and other manufacturing declined. The five least efficient industries turned out to be sports and athletic goods, surgical instruments, leather and leather products, manufacturing of textiles, and wearing apparel. It is important to note that all of these industries are export-oriented industries. Their low level of efficiency probably explains why the government has all along provided a host of incentives to such export-oriented industries i.e. to offset their inherent inefficiencies. 
Table 3

Industry-wise Mean Efficiency Scores

\begin{tabular}{lccr}
\hline Industry & $1995-96$ & $2000-01$ & \%Change \\
\hline Tobacco Manufacturing & 0.88 & 0.87 & -0.84 \\
Petroleum Refining & 0.74 & 0.76 & 3.70 \\
Other Non-metallic Mineral Products & 0.72 & 0.67 & -6.39 \\
Other Manufacturing & 0.71 & 0.61 & -14.14 \\
Electrical Machinery and Supplies & 0.69 & 0.70 & 0.08 \\
Pottry, China and Earthware & 0.68 & 0.65 & -2.40 \\
Industrial Chemicals & 0.66 & 0.72 & 8.45 \\
Other Chemical Products & 0.66 & 0.64 & -4.25 \\
Printing and Publishing & 0.66 & 0.73 & 24.33 \\
Glass and Glass Products & 0.66 & 0.56 & -15.10 \\
Paper and Paper Products & 0.65 & 0.66 & 2.19 \\
Drugs and Pharmaceutical Products & 0.63 & 0.67 & 8.76 \\
Iron and Steel & 0.60 & 0.75 & 25.34 \\
Fabricated Metal Product & 0.59 & 0.67 & 13.86 \\
Rubber Products & 0.57 & 0.73 & 30.25 \\
Food Manufacturing & 0.56 & 0.58 & 16.11 \\
Transport Equipment & 0.56 & 0.53 & -6.79 \\
Non-Ferrous Metal Industries & 0.54 & 0.78 & 46.69 \\
Non-electrical Machinery & 0.49 & 0.62 & 30.61 \\
Ginning and Baling of Fibre & 0.48 & 0.73 & 51.30 \\
Wearing Apparel & 0.47 & 0.56 & 18.28 \\
Manufacturing of Textiles & 0.46 & 0.59 & 39.47 \\
Leather and Leather Products & 0.41 & 0.72 & 81.09 \\
Surgical Instruments & 0.30 & 0.58 & 90.44 \\
Sports and Athletic Goods & 0.30 & 0.77 & 154.58 \\
\hline
\end{tabular}

The situation is somewhat different in 2000-01, when sports and athletic goods, non-ferrous metals, and iron and steel made into the top five efficient industries. Most remarkable is the turnaround shown by the sports and athletic goods which earlier ranked among the least five efficient industries. Among the five least efficient industries are transport equipment, wearing apparel, glass and glass products, surgical instruments, and food manufacturing. It is noteworthy that the textiles and manufacturing is only marginally better off as compared with 1995-96 lying a notch above the 5 least efficient industries.

The efficiency scores of a diverse range of industries including textiles manufactures, food manufacturing, industrial chemicals, iron and steel, drugs and pharmaceutical products, electrical machinery and supplies, and nonelectrical machinery etc. indicate improvement in efficiency over time. ${ }^{9}$ It is

${ }^{9} \mathrm{~A}$ comparison of efficiency scores across two different production frontiers is akin to Battese, Rao, and O'Donnell (2004) who compare efficiency levels of different groups in terms of their own frontier as well as a metafrontier. 
important to note that while efficiency levels have improved, big gaps remain in terms of the location of firms from the frontier: for example, in 2000-01, the mean efficiency score ranged from 0.53 (transport equipment) to 0.87 (tobacco manufacturing). This implies that there is considerable room for improvement in the efficiency levels of these industries.

There has been a decline in efficiency of other non-metallic mineral products, tobacco manufacturing, transport equipment, other chemical products, pottery, china and earthenware, and glass and glass products. The highest decline is recorded by glass and glass products (15.10 percent) followed by transport equipment (6.79 percent), other non-metallic products (6.39 percent), other chemical products (4.25 percent), pottery, china and earthenware (2.4 percent) and tobacco manufacturing ( 0.84 percent $)$.

\section{CONCLUDING REMARKS}

This paper has examined the efficiency of the large scale manufacturing sector of Pakistan using the stochastic production frontier approach. A stochastic production frontier is estimated for two periods-1995-96 and 2000-01 - for 101 industries at the PSIC 5-digit level. The results show that there has been some improvement in the efficiency of the large scale manufacturing sector, though the magnitude of improvement remains small. The results are mixed at the disaggregated level: whereas a majority of industrial groups have gained in terms of technical efficiency, some industries have shown deterioration in their efficiency levels including, for example, transport equipment, glass and glass products, other non-metallic mineral products, and other manufacturing. There may be several factors that may have caused a decline in the technical efficiency of such firms, not least the trade policy environment that may have shielded such industries from external competition. Further research may focus on the specific determinants of technical efficiency including the macroeconomic and trade policy environment. 
APPENDIX

Efficiencies Scores at Industry Level

\begin{tabular}{|c|c|c|c|c|}
\hline & & $1995-96$ & $2000-01$ & \%Change \\
\hline Group 1 & Manufacturin & Textiles & & \\
\hline 32011 & Cotton spinning & 0.39 & 0.57 & 47.60 \\
\hline 32012 & Cotton weaving & 0.43 & 0.48 & 11.50 \\
\hline 32020 & Woolen textiles & 0.59 & 0.66 & 11.30 \\
\hline 32030 & Jute textiles & 0.52 & 0.56 & 7.63 \\
\hline 32040 & Silk and art silk textiles & 0.49 & 0.62 & 28.25 \\
\hline 32050 & Narrow fabrics & 0.27 & 0.84 & 213.48 \\
\hline 32070 & Finishing of textiles & 0.38 & 0.50 & 33.08 \\
\hline 32120 & Made up textile goods & 0.44 & 0.48 & 8.60 \\
\hline 32130 & Knitting mills & 0.33 & 0.54 & 62.39 \\
\hline 32150 & Cordage, rope and twine & 0.61 & 0.61 & -0.86 \\
\hline \multirow[t]{2}{*}{32160} & Spooling and thread ball making & 0.57 & 0.63 & 11.16 \\
\hline & Average (Group 1) & 0.46 & 0.59 & 39.47 \\
\hline Group 2 & \multicolumn{4}{|c|}{ Food Manufacturing } \\
\hline 31121 & Dairy products & 0.56 & 0.51 & -8.82 \\
\hline 31122 & Ice cream & 0.60 & 0.78 & 29.46 \\
\hline 31130 & Canning of fruits and vegetables & 0.63 & 0.80 & 26.01 \\
\hline 31140 & Canning of fish and sea food & 0.48 & 0.42 & -11.97 \\
\hline 31151 & Vegetable Ghee & 0.54 & 0.78 & 45.64 \\
\hline 31153 and 59 & Cotton seed and inedible animal oils & 0.59 & 0.56 & -4.75 \\
\hline 31161 & Rice milling & 0.41 & 0.53 & 29.23 \\
\hline 31162 & Wheat and grain milling & 0.19 & 0.58 & 209.63 \\
\hline 31163 and 69 & Grain milled products and other grain milling & 0.75 & 0.69 & -8.23 \\
\hline 31171 & Bread and bakery products & 0.50 & 0.67 & 34.74 \\
\hline 31172 & Biscuits & 0.52 & 0.60 & 14.91 \\
\hline 31181 & Refined sugar & 0.64 & 0.65 & 0.73 \\
\hline 31191 & Confectionery, not sweetmeats & 0.64 & 0.44 & -31.22 \\
\hline 31192 and 99 & "Desi" sweetmeats and confectionery & 0.72 & 0.37 & -48.52 \\
\hline 31212 & Blending of tea & 0.71 & 0.49 & -31.35 \\
\hline 31221 & Feeds for animals & 0.51 & 0.77 & 52.13 \\
\hline 31222 & Feeds for fowls & 0.23 & 0.45 & 97.86 \\
\hline 31291 & Starch & 0.71 & 0.69 & -3.40 \\
\hline 31292 & Edible salt & 0.80 & 0.72 & -9.52 \\
\hline \multirow[t]{2}{*}{31293} & Ice & 0.45 & 0.18 & -60.29 \\
\hline & Average (Group 2) & 0.56 & 0.58 & 16.11 \\
\hline Group 3 & \multicolumn{4}{|c|}{ Industrial Chemicals } \\
\hline 35111 & Alkalies & 0.60 & 0.72 & 20.12 \\
\hline 35112 & Acids, salts and intermediates & 0.63 & 0.76 & 21.34 \\
\hline 35113 & Sulphuric acid & 0.68 & 0.57 & -16.63 \\
\hline 35120 & Dyes, colours and pigments & 0.70 & 0.76 & 8.77 \\
\hline 35130 & Compressed gases, etc. & 0.61 & 0.70 & 15.48 \\
\hline 35140 & Fertilisers & 0.69 & 0.73 & 5.69 \\
\hline 35150 & Pesticides, insecticides, etc. & 0.67 & 0.79 & 18.08 \\
\hline \multirow[t]{2}{*}{35160} & Synthetic resins, etc. & 0.74 & 0.70 & -5.28 \\
\hline & Average (Group 3) & 0.66 & 0.72 & 8.45 \\
\hline \multirow[t]{2}{*}{36910} & Bricks and tiles & 0.63 & 0.64 & 1.60 \\
\hline & & $1995-96$ & $2000-01$ & $\%$ Change \\
\hline 36920 & Cement & 0.73 & 0.72 & -1.35 \\
\hline \multirow[t]{2}{*}{36930} & Cement products & 0.79 & 0.64 & -19.43 \\
\hline & Average (Group 4) & 0.72 & 0.67 & -6.39 \\
\hline Group 5 & Tobacco Mar & cturing & & \\
\hline 31410 & Cigarettes & 0.88 & 0.87 & -0.84 \\
\hline
\end{tabular}




\begin{tabular}{|c|c|c|c|c|}
\hline Group 6 & Iron and $\mathbf{S t}$ & & & \\
\hline 37110 & Iron and steel mills & 0.60 & 0.75 & 25.34 \\
\hline Group 7 & Drugs and pharmaceu & tical proc & & \\
\hline 35010 & Medicines and basic drugs(allopathic) & 0.54 & 0.74 & 36.17 \\
\hline 35020 & "Unani" medicines & 0.68 & 0.77 & 12.60 \\
\hline 35040 and 90 & Homeopathic and other medicinal preparation & 0.67 & 0.52 & -22.50 \\
\hline & Average (Group 7) & 0.63 & 0.67 & 8.76 \\
\hline Group 8 & Electrical Machinary & and Supp & & \\
\hline 38310 & Electrical industrial machinery & 0.70 & 0.67 & -4.43 \\
\hline 38320 & Radio and television commu & 0.77 & 0.73 & -5.11 \\
\hline 38330 & Electrical appliances & 0.76 & 0.81 & 7.18 \\
\hline 38340 & Insulated wires and cables & 0.75 & 0.71 & -5.96 \\
\hline 38350 & Electrical bulbs and tubes & 0.50 & 0.48 & -3.16 \\
\hline 38360 & Batteries & 0.69 & 0.77 & 11.97 \\
\hline & Average (Group 8) & 0.69 & 0.70 & 0.08 \\
\hline Group 9 & Transport Equ & pment & & \\
\hline 38440 & Motor vehicles & 0.60 & 0.63 & 5.20 \\
\hline 38450 & Motor cycles, auto rickshaws & 0.47 & 0.35 & -25.62 \\
\hline 38460 & Cycles and pedicabs & 0.62 & 0.62 & 0.04 \\
\hline & Average (Group 9) & 0.56 & 0.53 & -6.79 \\
\hline Group 10 & Other Chemical I & roducts & & \\
\hline 35210 & Paints, varnishes and lacquers & 0.74 & 0.67 & -8.46 \\
\hline 35220 & Perfumes and cosmetics & 0.67 & 0.66 & -0.91 \\
\hline 35230 & Soap and detergents & 0.76 & 0.71 & -7.49 \\
\hline 35240 & Polishes and waxes & 0.72 & 0.78 & 8.42 \\
\hline 35260 & Ink (all kinds) & 0.40 & 0.35 & -12.84 \\
\hline & Average (Group 10) & 0.66 & 0.64 & -4.25 \\
\hline Group 11 & Non-electrical Ma & chinery & & \\
\hline 38210 & Engines and turbines & 0.37 & 0.56 & 49.62 \\
\hline 38220 & Agricultural machinery & 0.51 & 0.63 & 24.10 \\
\hline 38230 & Metal and wood working machinery & 0.45 & 0.66 & 47.33 \\
\hline 38240 & Textile machinery & 0.62 & 0.62 & 1.38 \\
\hline & Average (Group 11) & 0.49 & 0.62 & 30.61 \\
\hline Group 12 & Printing and Pul & lishing & & \\
\hline 34210 & Newspapers & 0.76 & 0.76 & 0.53 \\
\hline 34220 & Books, periodicals, maps, etc. & 0.35 & 0.73 & 109.95 \\
\hline 34230 & Job printing & 0.83 & 0.75 & -9.52 \\
\hline 34240 & Printed cards and stationery & 0.68 & 0.66 & -3.62 \\
\hline & Average (Group 12) & $\begin{array}{r}\mathbf{0 . 6 6} \\
1995-96\end{array}$ & $\begin{array}{r}\mathbf{0 . 7 3} \\
2000-01\end{array}$ & $\begin{array}{r}24.33 \\
\text { \%Change }\end{array}$ \\
\hline Group 13 & Petroleum Ref & ining & & \\
\hline 353 and 354 & $\begin{array}{l}\text { Petroleum refining and products of petroleum } \\
\text { and coal }\end{array}$ & 0.74 & 0.76 & 3.70 \\
\hline Group 14 & Paper and Paper I & Products & & \\
\hline 34110 & Pulp and paper & 0.64 & 0.70 & 8.76 \\
\hline 34120 & Paperboard & 0.59 & 0.69 & 16.01 \\
\hline 34130 & Pulp, paper and board articles & 0.70 & 0.57 & -18.19 \\
\hline & Average (Group 14) & 0.65 & 0.66 & 2.19 \\
\hline Group 15 & Wearing App & arel & & \\
\hline 32210 & Ready-made garments & 0.47 & 0.56 & 18.28 \\
\hline Group 16 & Leather and Leathe & r produc & & \\
\hline 32310 & Tanning and leather finishing & 0.41 & 0.70 & 70.51 \\
\hline
\end{tabular}




\begin{tabular}{|c|c|c|c|c|}
\hline \multicolumn{5}{|c|}{ Appendix-(Continued $)$} \\
\hline 32330 & Leather products excepts footwear & 0.31 & 0.68 & 120.32 \\
\hline \multirow[t]{2}{*}{32410} & Leather foot-wear & 0.50 & 0.77 & 52.42 \\
\hline & Average (Group 16) & 0.41 & 0.72 & 81.09 \\
\hline Group 17 & \multicolumn{4}{|c|}{ Ginning and Baling of Fibre } \\
\hline 32510 and 90 & Ginning (Cotton and others) & 0.48 & 0.73 & 51.30 \\
\hline Group 18 & \multicolumn{4}{|c|}{ Rubber Products } \\
\hline 35510 & Tyres and tubes & 0.70 & 0.79 & 13.36 \\
\hline 35520 & Retreading tyres and tubes & 0.53 & 0.72 & 37.30 \\
\hline 35591 & Rubber foot-wear & 0.57 & 0.71 & 25.63 \\
\hline 35592 & Vulcanised rubber products & 0.59 & 0.71 & 19.84 \\
\hline \multirow[t]{2}{*}{35593} & Rubber belting & 0.45 & 0.70 & 55.13 \\
\hline & Average (Group 18) & 0.57 & 0.73 & 30.25 \\
\hline Group 19 & \multicolumn{4}{|c|}{ Pottery, China and Earthware } \\
\hline 36120 & China and ceramics & 0.60 & 0.68 & 13.22 \\
\hline \multirow[t]{2}{*}{36110 and 90} & Earthenware and other pottery & 0.76 & 0.62 & -18.01 \\
\hline & Average (Group 19) & 0.68 & 0.65 & -2.40 \\
\hline Group 20 & \multicolumn{4}{|c|}{ Glass and Glass Products } \\
\hline 36210 & Glass & 0.69 & 0.50 & -27.78 \\
\hline \multirow[t]{2}{*}{36220} & Glass products & 0.64 & 0.63 & -2.42 \\
\hline & Average (Group 20) & 0.66 & 0.56 & -15.10 \\
\hline Group 21 & \multicolumn{4}{|c|}{ Non-ferrous Metal Industries } \\
\hline 37210 & Aluminium and aluminium alloys & 0.49 & 0.84 & 72.84 \\
\hline \multirow[t]{2}{*}{37220} & Copper and copper alloys & 0.59 & 0.71 & 20.55 \\
\hline & Average (Group 21) & 0.54 & 0.78 & 46.69 \\
\hline Group 22 & \multicolumn{4}{|c|}{ Fabricated Metal Products } \\
\hline 38010 & Cutlery & 0.52 & 0.60 & 15.21 \\
\hline 38050 & Structural metal products & 0.57 & 0.67 & 16.93 \\
\hline 38060 & Metal stamping, coating, etc. & 0.60 & 0.85 & 40.94 \\
\hline 38070 & Heating and cooking equipment & 0.69 & 0.84 & 21.06 \\
\hline 38080 & Wire product & 0.47 & 0.46 & -1.06 \\
\hline 38090 & Utensils - aluminium & 0.70 & 0.64 & -9.35 \\
\hline \multirow[t]{2}{*}{38140} & Tin cans and tinware & 0.71 & 0.61 & -13.20 \\
\hline & & $1995-96$ & $2000-01$ & \%Change \\
\hline \multirow[t]{2}{*}{38150 and 60} & Metal trunks and bolt s, nuts, rivets, etc. & 0.48 & 0.68 & 40.34 \\
\hline & Average (Group 22) & 0.59 & 0.67 & 13.86 \\
\hline Group 23 & \multicolumn{4}{|c|}{ Surgical Instruments } \\
\hline 38510 & Surgical instruments & 0.30 & 0.58 & 90.44 \\
\hline Group 24 & \multicolumn{4}{|c|}{ Sports and Athletic Goods } \\
\hline 392 & Sports and athletic goods & 0.30 & 0.77 & 154.58 \\
\hline Group 25 & \multicolumn{4}{|c|}{ Lime, Plaster and Manufacture of Refractories } \\
\hline 36940 and 50 & Lime, plaster and manufacture of refractories & 0.06 & 0.33 & 413.75 \\
\hline Group 26 & Other Manufa & cturing & & \\
\hline \multirow[t]{2}{*}{39420} & Bone crushing & 0.71 & 0.61 & -14.14 \\
\hline & Average (All Industries) & 0.58 & 0.65 & 11.94 \\
\hline
\end{tabular}




\section{REFERENCES}

Afriat, S. N. (1972) Efficiency Estimation of Production Functions. International Economic Review 13, 568-598.

Aigner, Dennis, C. A. Knox Lovell, and Peter Schmidt (1977) Formulation and Estimation of Stochastic Frontier Production Function Models. Journal of Econometrics 6, 21-37.

Alvares, Roberto, and Gustave Crespi (2003) Determinant of Technical Efficiency in Small Firms. Small Business Economics 20, 233-244.

Angeriz, Alvaro, John McCombie, and Mark Roberts (2006) Productivity, Efficiency and Technological Change in European Union Regional Manufacturing: a Data Envelopment Analysis Approach. The Manchester School 74: 4, Special Issue 1463-6786 pp. 500-525.

Battese, G. E., and G. S. Corra (1977) Estimation of a Production Frontier Model: With Application to the Pastoral Zones of Eastern Australia. Australian Journal of Agricultural Economics 21:3, 169-179.

Battese, G. E., and T. J. Coelli (1988) Prediction of Firm-Level Technical Efficiencies With a Generalised Frontier Production Function and Panel Data. Journal of Econometrics 38, 387-399.

Battese, George E., Rao, and O’Donnell (2004) A Metafrontier Production for Estimation of Technical Efficiencies and Technology Gaps for Firms Operating Under Different Technologies. Journal of Productivity Analysis 21:1, 91-103.

Burki, Abid A. and Mahmood-ul-Hasan Khan (2005) Effects of Allocative Inefficiency on Resource Allocation and Energy Substitution in Pakistan's Manufacturing. Lahore University of Management Sciences. (CMER Working Paper No. 04-30).

Coelli, T. J. (1994) A Guide to FRONTIER Version 4.1: A Computer Programme for Stochastic Frontier Production and Cost Function Estimation. Centre for Efficiency and Productivity Analysis, University of New England, Australia. (CEPA Working Paper 96/070.)

Coelli, T. J. (1995) Estimators and Hypothesis Tests for a Stochastic Frontier Function: A Monte Carlo Analysis. Journal of Productivity Analysis 6:4, 247-268.

Greene, W.H. (1990) A Gamma-distributed Stochastic Frontier Model. Journal of Econometrics 46, 141-164.

Ikhsan-Modjo, Mohamad (2006) Total factor Productivity in Indonesian Manufacturing: A Stochastic Frontier Approach. Monash University. (ABERU Discussion Paper 28).

Jajri, Idris, and Rahmah Ismail (2006) Technical Efficiency, Technological Change and Total Factor Productivity Growth in Malaysian Manufacturing Sector. MPRA (Munich Personal RePEc Archive Paper No. 1966), downloaded from: http://mpra.ub.uni-muenchen.de/1966/01/MPRA_paper_1966.pdf 
Kumbhakar, Subal C., and C. A. Knox Lovell (2000) Stochastic Frontier Analysis. Cambridge University Press.

Lee, Jeong Ye on, and Kim, Jung Woe (2006) Total Factor Productivity and R \& D Capital in Manufacturing Industries. East West Center (Working Paper 89, June).

Njikam, Ousmanou (2003) Trade Reform and Efficiency in Cameroon's Manufacturing Industries. African Economic Research Consortium, Nairobi. (AERC Research Paper 133.)

Pakistan, Government of (1996) Census of Manufacturing Industries-1995-96. Federal Bureau of Statistics (FBS).

Pakistan, Government of (2001) Federal Bureau of Statistics (FBS). http://www.statpak.gov.pk/depts/fbs/statistics/manufacturing_industry/cmi_ 2001.html

Pakistan, Government of (Various Issues) Economic Survey. Islamabad: Ministry of Finance.

Roberto Alvarez and Gustavo Crespi, (2003) Determinants of Technical Efficiency in Small Firms. Kluwer Academic Rublishers. Small Business Economics 20, 233-244,

Saranga, Haritha, and B.V. Phani (2004) The Indian Pharmaceutical IndustryAn Overview of Internal Efficiencies Using Data Envelopment Analysis. Indian Institute of Management Calcutta. (WPS-495, March).

Stevenson, R. E. (1980) Likelihood Functions for Generalised Stochastic Frontier Estimation. Journal of Econometrics 13, 57-66.

Taymaz, Erol, and Gulin Saatci (1997) Technical Change and Efficiency in Turkish Manufacturing Industries. Journal of Productivity Analysis 8, 461475.

Tripathy, Sabita (2006) Are Foreign Firms Allocatively Inefficient?: A Study of Selected Manufacturing Industries in India. Paper presented at the Fifth Annual GEP Postgraduate Conference (Leverhulme Centre for Research on Globalisation and Economic Policy (GEP), Nottingham. http://www. nottingham.ac.uk/economics/leverhulme/conferences/postgrad_conf_2006/Tr ipathy1.pdf 